\title{
. Preparation of isolated periportal or perivenous hepatocytes from rat liver.
}

Quistorff, Bjørn

Published in:

Methods in Molecular Biology

Publication date:

1990

Document version

Publisher's PDF, also known as Version of record

Citation for published version (APA):

Quistorff, B. (1990). . Preparation of isolated periportal or perivenous hepatocytes from rat liver. Methods in Molecular Biology, Chapt. 16, 177-188. 


\section{Chapter 16}

\section{Preparation of Isolated \\ Periportal or Perivenous \\ Hepatocytes from Rat Liver}

\section{Bjørn Quistorff}

\section{Introduction}

There are a number of functional, metabolic differences between periportal and perivenous hepatocytes in the mammalian liver resulting from zonal differences in the activity of several enzymes, and possibly from morphological differences as well (1). Examples of key enzymes where the periportal/perivenous activity ratio is $>1$ are glucose- 6 -phosphatase (2), phosphoenolpyruvate carboxykinase (3), alanine aminotransferase (4), ornithine carbamoyltransferase (5), and carbamoylphosphate synthetase (6), whereas enzymes such as glucokinase (7), P-450-dependent hydroxylation reactions (8), and glutamine synthetase (9) show the opposite zonation. Recent studies on lipogenic enzymes (acetyl-CoA carboxylase, citrate lyase, and fatty acid synthase) show that, although there is a periportal predominance in both the fed and fasted male rat, the ca. threefold enzyme induction observed after a fasting-refeeding transition takes place almost entirely in the perivenous zone (10).

It is clear that this metabolic heterogeneity that develops a few weeks after birth is closely related to the microcirculatory pattern of the liver (1). However, the signals responsible for the heterogenous expression of the 
hepatocte genome as a function of location in the microcirculation are unknown at present, although the gradients of oxygen (11) and hormones (12) are implicated. The physiological significance of zonation is largely unknown. In case of ammonia fixation it has been suggested that urea synthesis located in the inlet part of the microcirculation serves as the main process of ammonia fixation, whereas the high affinity system of glutamine synthesis located at the very outlet of the liver is considered the backup system for ammonia removal (13).

Thus, it is of considerable interest to study isolated periportal and perivenous hepatocytes separately. Several attempts have been made to separate isolated hepatocytes according to various physical and chemical characteristics, but generally with limited success. Recently, however, it was observed that digitonin perfusion allowed selective destruction of the periportal or perivenous part of the microcirculation (14), and by applying this principle in combination with traditional collagenase cell isolation (see Chapter 14), a method was developed for high-yield preparation of isolated hepatocytes enriched in either periportal or perivenous cells $(15,16)$. Applying this technique, periportal predominance of the pathways of gluconeogenesis $(16,17)$ and urea synthesis $(17,18)$ in freshly islolated cells as well as in primary culture has now been demonstrated. A number of review papers on the topic of metabolic zonation of the liver have appeared $(1,19,20,21)$.

\section{Materials}

1. Rats weighing 170-190 g. Animals are anesthetized with pentobarbital ip; $400 \mu \mathrm{L}, 50 \mathrm{mg} / \mathrm{kg}$.

2. Perfusion system: Switching between forward and reverse perfusion as well as switching between different perfusates may be done manually. We find it advantageous, however, to use a valve system as the one shown schematically in Fig. 1, e.g., Hamilton miniature valves (Hamilton Bonaduz AG, CH-7402 Switzerland) type HV 86729 for the switching of low direction and two type HV 86727 valves for perfusate switching.

Alternatively miniature pinch-solenoid valves may be used. Our current perfusion system is based on such 3-way valves (model S305$01 \mathrm{EG}$; Sirai Inc., Italy). The perfusion system is convenient to operate and ensures rapid and precise switching with a very small dead-space in the tubing system. Furthermore, the perfusion system is readily computer controlled, e.g., for more complicated perfusion sequences (22). The system is shown schematically in Fig. 2. 


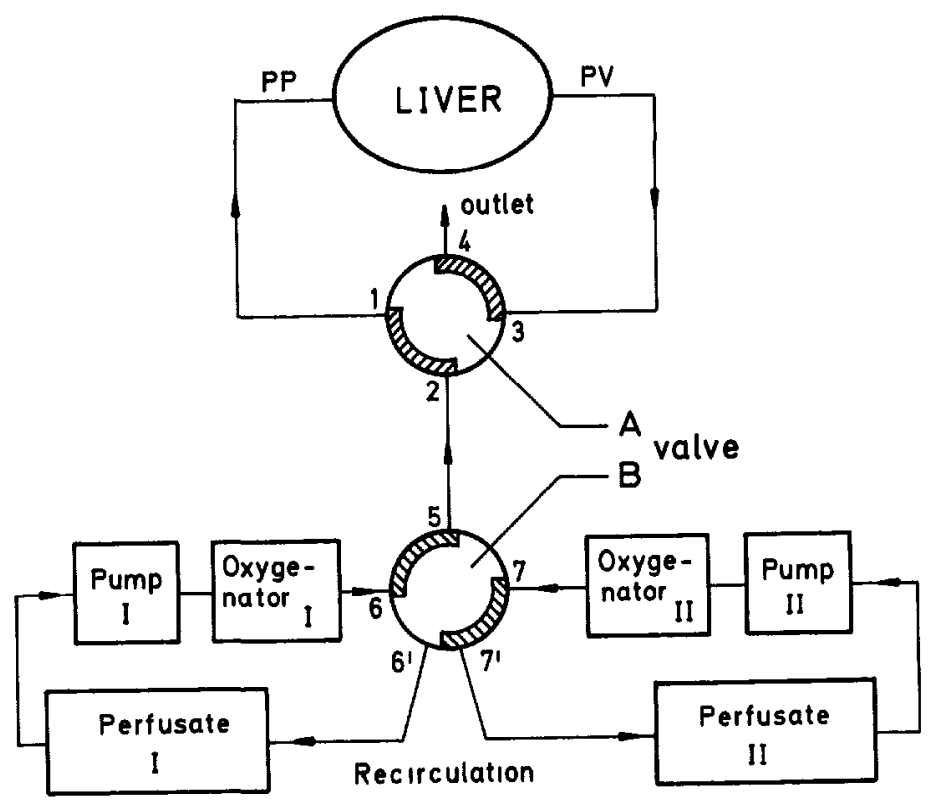

Fig. 1. Schematic perfusion setup for preparation of isolated periportal and perivenous hepatocytes. The liver is connected to the perfusion system via the portal vein (PP) and the v. cava sup. (PV). A $90^{\circ}$ turn of valve A switches the flow direction through the liver from $\mathrm{P} \rightarrow \mathrm{C}$ to $\mathrm{C} \rightarrow \mathrm{P}$. A $90^{\circ}$ turn of valve $\mathrm{B}$ switches the perfusate from I to II.

3. Solution I: $118 \mathrm{mM} \mathrm{NaCl}, 4.7 \mathrm{mM} \mathrm{KCl}, 1.2 \mathrm{mM} \mathrm{KH} \mathrm{PO}_{4^{\prime}} 1.2 \mathrm{mM}$ $\mathrm{MgSO}_{4}$, and $25 \mathrm{mM} \mathrm{NaHCO}_{3}$.

4. Solution II: As solution I plus $3 \mathrm{mM} \mathrm{CaCl}$ and $0.2-0.4 \mathrm{mg} / \mathrm{mL}$ collagenase.

5. Solution III: As solution I plus $1.2 \mathrm{mM} \mathrm{CaCl}$.

6. Solution IV: As solution I plus $4 \mathrm{mg} / \mathrm{mL}$ digitonin.

All solutions (I-IV) are kept in a thermostated water bath at $39^{\circ} \mathrm{C}$ during the cell isolation procedure, constantly equilibrated with oxygen/carbon dioxide (19:1, vol/vol), except for solution IV, which is gassed only until the addition of the digitonin, a few minutes before use.

7. Equipment as described in Chapter 14, except that two roller type pumps (LKB MultiPerpex 2115, Bromma, Sweden) are used. A bubble trap is mounted on the infusion line between valve A and B, Fig. 1.

8. Digitonin: Commercial preparation of digitonin vary considerably in terms of purity and in terms of water solubility. We usually use the SIGMA digitonin. In order to obtain good water solubility, the following purification steps are necessary. Five $g$ of digitonin is dissolved in $150 \mathrm{~mL}$ boiling methanol $\left(65^{\circ} \mathrm{C}\right)$. This solution is cooled to $45^{\circ} \mathrm{C}$ and 


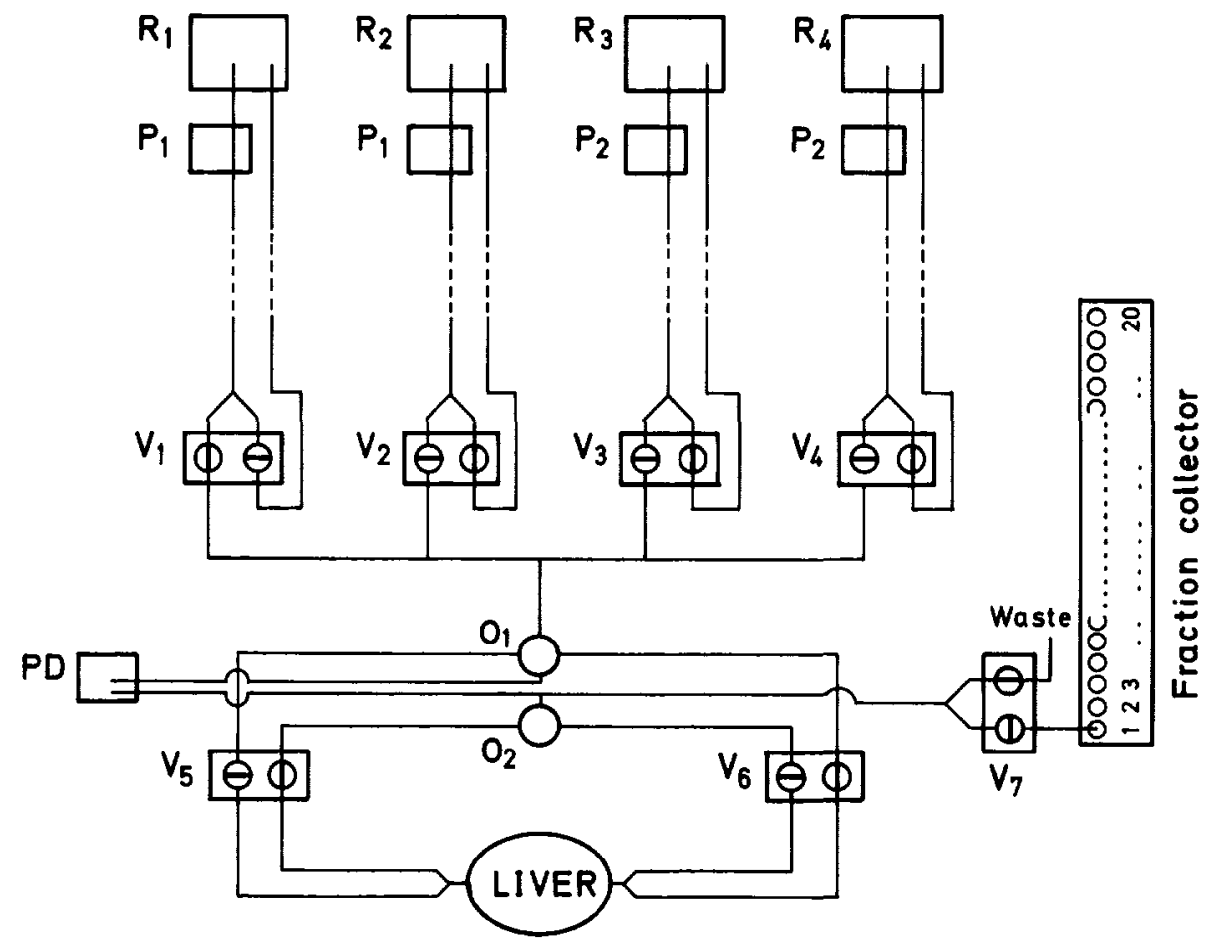

Fig. 2. Schematic perfusion setup based on three-way micro-pinch-solenoid valves. The liver is connected to the perfusion system as in Fig. 1. The valves V5 and V6 are operated synchroneously, switching the perfusion direction through the liver. 01 and 02 are two Clarck type of oxygen electrodes mounted on the infusion line and on the out flow line from the liver, respectively. PD is a pressure difference gage. V7 regulates whether the eluate from the liver is collected or discarded. V1-V4 regulate which of four different perfusates are being infused. When one of these valves is not selected, the perfusate is automatically recycled to the proper reservoir, R1-R4. P1-P4 are different decks on the multiperpex pump or, alternatively, different pumps, e.g., used for fast switching of flow rate $(21,22)$.

precipitated by addition of $450 \mathrm{~mL}$ room temperature diethyl ether. The suspension is filtered on a Buckner funnel. After three washings with diethyl ether, the remnant is collected from the funnel, resuspended in water, and freeze-dried for $2-3 \mathrm{~d}$ in order to remove all diethyl ether. The freeze-dried digitonin is weighed and redissolved in water $(5 \mathrm{~mL})$ in portions of $150 \mathrm{mg}$ digitonin, which is the amount used for each experiment. After centrifugation ( $20000 \mathrm{~g} \times \mathrm{min}$ ), the super- 
natant is freeze-dried overnight and kept in the powder form in the same tube until use.

Note that digitonin is toxic and easily absorbed through the skin. Handling should be done carefully, wearing gloves, and weighing of the fluffy, freeze-dried powder should be done in a hood.

9. Collagenase (type II) is used.

\section{Method}

The principle of the technique is to destroy selectively cells of either the periportal or perivenous part of the liver microcirculation with digitonin and then perform a standard collagenase cell isolation on the remaining part. Thus, only periportal or perivenous hepatocytes may be prepared from one liver. Table 1 lists the essential steps of the procedure.

1. A method for establishing the initial perfusion of the liver with KrebsHenseleit buffer (solution III) is as described in Chapter 14. After 5-10 min of perfusion, the small caudate liver lobe is routinely ligated, and cut off (approximately $0.3 \mathrm{~g}$ of tissue) and homogenized in ice-cold buffer (solution III with $5 \mathrm{mM}$ dithiotreitol). This sample (the start biopsy) is used for analysis of marker enzymes in order to quantitiate the zonal purity of the prepared cells (see Note 2).

2. The selective destruction of perivenous cells in order to isolate periportal cells is described first (see also Table 1). Flow direction is switched to cava $\rightarrow$ porta, and flow rate is decreased to $7 \mathrm{~mL} / \mathrm{min}$.

3. Thirty seconds later, the digitonin containing perfusate (solution IV) is switched on and the liver surface is observed. Because of complexing with cholesterol, the digitonin will progressively destroy the plasma membrane of the cells along the path of the microcirculation. Experience has shown that under the present conditions it is possible to achieve a largely synchroneous destruction of the sinusoids, which advance slowly along the path of the perfusate, 50-100-fold slower than the linear flow rate (14). This is demonstrated very clearly on the liver surface by the development over $30-50 \mathrm{~s}$ of a pattern of pale, white spots in the perivenous areas (the dark-brown spots on the normal liver). The goal is to continue the digitonin perfusion until a regularly scattered perivenous decoloration pattern on the liver surface is obtained as demonstrated in Fig. 3B. Under the present conditions, this involves $30-45 \mathrm{~s}$ of perfusion.

4. The perfusion is then switched to the calcium-free perfusate (solution I), and a few seconds later (when the digitonin perfusate in the tubing 
Table 1

Essential Steps in the Preparation of Periportal or Perivenous Hepatocytes

\begin{tabular}{|c|c|c|c|c|}
\hline & $\begin{array}{l}\text { Flow rate, } \\
\mathrm{mL} / \mathrm{min} \\
\text { flow } \\
\text { direction }\end{array}$ & $\begin{array}{l}\text { Time } \\
\min \end{array}$ & Samples & Buffer \\
\hline $\begin{array}{l}\text { 1. Initial } \\
\text { perfusion }\end{array}$ & $\begin{array}{l}30 \\
P \rightarrow C\end{array}$ & $10-15$ & Biopsy & Solution III \\
\hline $\begin{array}{l}\text { 2. Selective destruction } \\
\text { of PV cells" }\end{array}$ & $\begin{array}{l}7 \\
C \rightarrow P\end{array}$ & $0.5-1.0$ & & Solution IV \\
\hline $\begin{array}{l}\text { 3. Calcium } \\
\text { removal* }\end{array}$ & $\begin{array}{l}25 \\
P \rightarrow C\end{array}$ & $8-12$ & $\begin{array}{l}\text { Eluate } \\
\text { first } \\
20 \mathrm{~s}\end{array}$ & Solution I \\
\hline $\begin{array}{l}\text { 2a.Selective destruction } \\
\text { of PV cells }\end{array}$ & $\begin{array}{l}7 \\
P \rightarrow C\end{array}$ & $0.5-1.0$ & & Solution IV \\
\hline $\begin{array}{l}\text { 3a.Calcium } \\
\text { removal }\end{array}$ & $\underset{C \rightarrow P}{25}$ & $8-12$ & $\begin{array}{c}\text { Eluate } \\
\text { first } \\
20 \mathrm{~s}\end{array}$ & Solution I \\
\hline $\begin{array}{l}\text { 4. Collagenase } \\
\text { perfusion }\end{array}$ & $\underset{P \rightarrow C}{25}$ & $10-20$ & & $\begin{array}{l}\text { Solution II } \\
\text { (recircu- } \\
\text { lation) }\end{array}$ \\
\hline $\begin{array}{l}\text { 5. Rinse } \\
\text { cycle }\end{array}$ & $\stackrel{25}{P \rightarrow C}$ & $1-2$ & & Solution III \\
\hline 6. Incubation & & 10 & & Solution III \\
\hline $\begin{array}{l}\text { 7. Cell } \\
\text { separation, } \\
\text { washing }\end{array}$ & & & & Solution III \\
\hline
\end{tabular}

"Steps 2 and 3 are replaced by steps $2 a$ and $3 a$ in order to prepare perivenous cells instead of periportal cells.

between the liver and valve B, Fig. 1, is cleared), the flow direction is switched to porta $\rightarrow$ cava and flow rate increased to ca. $25 \mathrm{~mL} / \mathrm{min}$. Initial eluate (15 s) during this interval is collected in $200 \mu \mathrm{L} 40 \mathrm{mM}$ dithiotreitol for marker enzyme analysis (see Note 2).

5. The procedure for selective destruction of periportal cells in order to prepare perivenous cells is as described above, except that flow directions were opposite with periportal infusion of digitonin at a rate of 
A

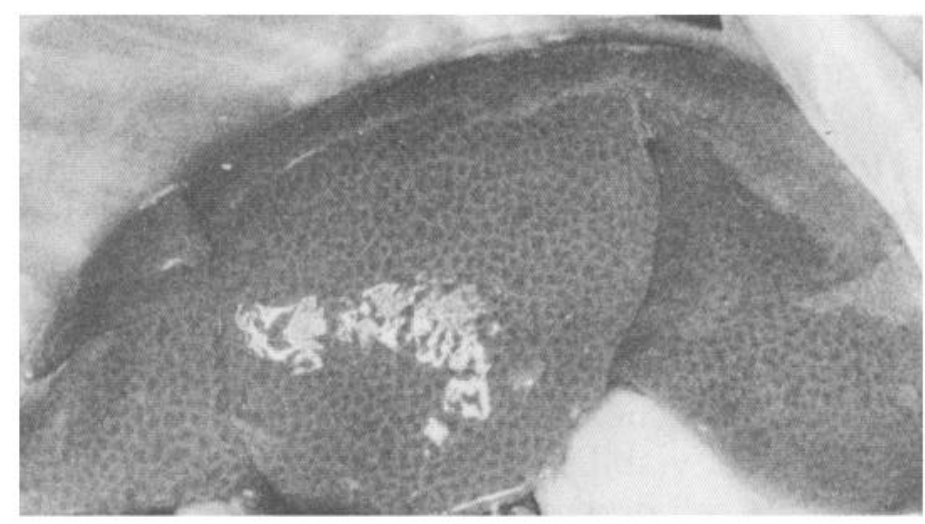

B

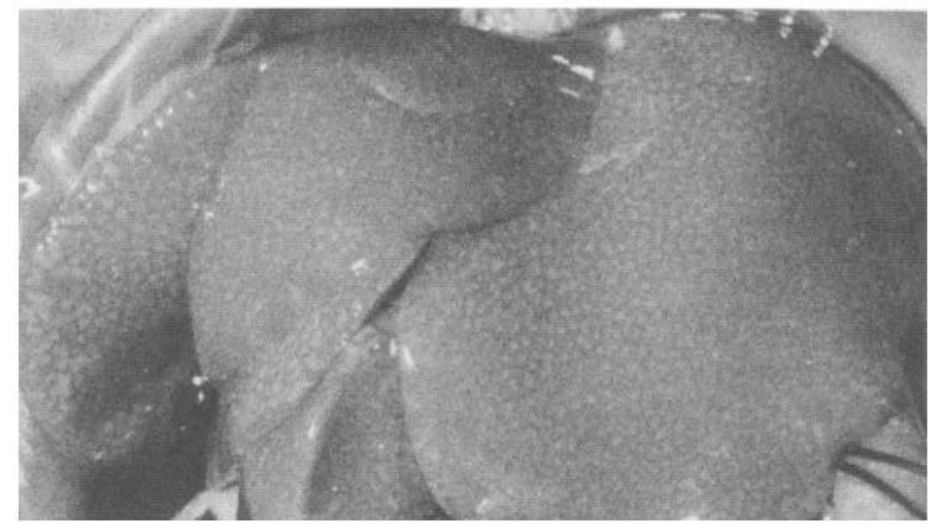

Fig. 3. Zone-specific decolorization of the liver after digitonin perfusion. A: Periportal decoloration pattern, obtained after $45 \mathrm{~s}$ of digitonin perfusion $4 \mathrm{mg} / \mathrm{mL}, 7 \mathrm{~mL} / \mathrm{min}$. B: The complementary perivenous pattern obtained after $45 \mathrm{~s}$ of digitonin perfusion 4 $\mathrm{mg} / \mathrm{mL}, 5.0 \mathrm{~mL} / \mathrm{min}$.

only $5 \mathrm{~mL} / \mathrm{min}$ (see Table 1 ). The decoloration pattern obtained is complementary to the pattern described above, now with pale, periportal spots rapidly developing into a network-like pattern, (see Fig. 3A).

6. The switch to the calcium-free buffer (solution I) initiates the standard hepatocyte preparation, which is described in detail in Chapter 14. 


\section{Notes}

1. Cell yields are usually higher for periportal than for perivenous cells, i.e., 1.3-2.0 $\times 10^{6}$ and 0.8-1.2 $\times 10^{6}$ cells, respectively $(15,16)$. It is essential to keep the flow rate low during digitonin perfusion. With a flow rate of $20 \mathrm{~mL} / \mathrm{min}$, the cell yield was ca. fivefold lower, even though the amount of digitonin infused under these conditions was the same as with the low flow (16). It may improve the yield of cells to include deoxyribonuclease $20 \mu \mathrm{g} / \mathrm{mL}$ during the incubation of the isolated cells, step 6 in scheme 1 (15).

In terms of viability, it is our experience that both periportal and perivenous cell preparations show the same viability of $85-95 \%$ unstained cells as judged by Trypan blue staining, which is not different from control cell preparations. Occasionally preparations of low viability occur. We recommend that such preparations be discarded. Alternatively, some separation of stained and unstained cells may be obtained (at the expense of cell yield) by metrisamide gradient centrifugation (15). (For other viability tests and metabolic competence cells, see Chapter 15.)

2. The purity of the cell preparation in terms of contamination of periportal cells to a preparation of perivenous cells and vice versa is determined by the "zonal specificity" of the digitonin destruction. It is clear from the pattern of marker enzymes eluted during continuous digitonin perfusion that ideal conditions of equal destruction of all sinusoids do not prevail (14), except for the initial eluation, which has a very high zonal specificity $[<1 \%$ contamination (22)]. Thus, a quantitative evaluation of the zonal purity of the final cell preparation is required. Figure 4 illustrates the problem schematically in a simplified model of the microcirculatory unit of the liver. Using this model, which assumes only two populations of hepatocytes, a quantitative evaluation may be attempted as explained below, based on the activity of alanine aminotransferase (ALAT), which is known to have a periportal/perivenous activity gradient of approximately 10-fold $(4,22)$.

In cell preparation obtained according to the method described above, we have measurements of ALAT specific activity:

a. in the start biopsy,

b. in the eluate obtained after digitonin perfusion and

c. in the final cell suspension. 


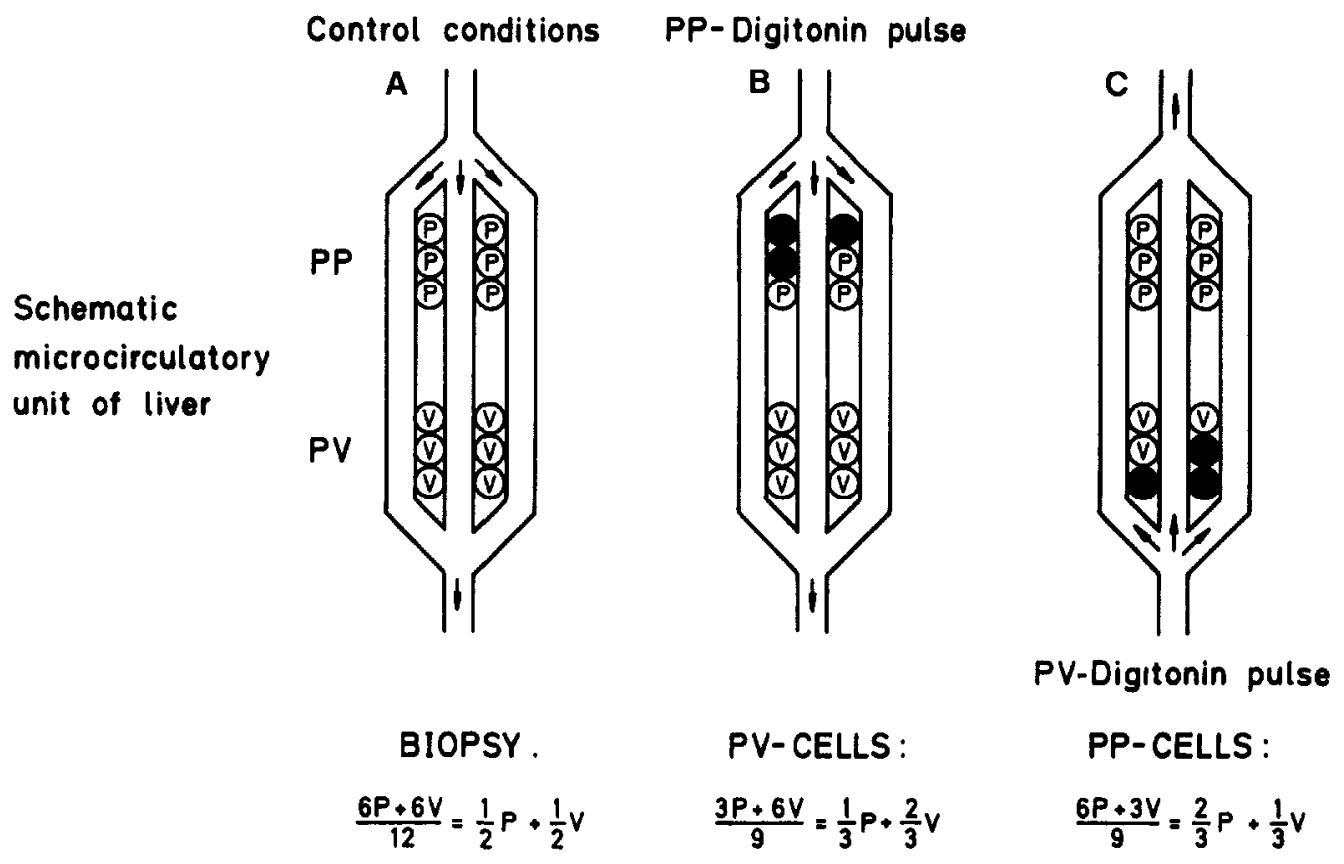

Fig. 4. Model of the liver microcirculation: effect of digitonin. The model assumes only two populations of hepatocytes, periportal (PP) and perivenous (PV), each of which is homogenous with respect to the parameter in question, but not necessarily of the same size. The figure shows two examples of selective destruction with a pulse of digitonin. $B$ shows periportal destruction, which, with ensuing collagenase cell isolation will give a cell preparation enriched in perivenous cells by $67 \%$ (see numeric example below figure). Conversly, $C$ shows the case of perivenous cell destruction.

Assuming the two-population model of Fig. 4, the volume fraction $v$ of periportal cells in the intact liver may be calculated to 0.52 (23). This value for $v$ may now be substituted in the equation

$$
\mathrm{Abi}=(v) \mathrm{App}+(1-v) \mathrm{Apv}
$$

where Abi is the specific activity of ALAT in the start biopsy, expressed as units/mg of cytosolic protein (see 23), while App and Apv is the specific activity in periportal and perivenous cells respectively (expressed as units / $\mathrm{mg}$ of cytosolic protein). Since in one particular experiment either App or Apv is known (measured in the initial eluate collected during digitonin perfusion), the other may be calculated. The values obtained for App and Apv may now be substituted in the equation 


$$
\text { Acell }=(f) \text { App }+(1-f) \text { Apv }
$$

where Acell is the specific activity in the actual preparation of periportal or perivenous cells, $f$ the fraction of periportal cells, and conversely (1- $f$ ) the fraction of perivenous cells.

This relation thus allows calculation of the purity of the cell preparation $(f$ or $l-f)$ under the assumption of a two-population model for the distribution of the enzyme in question. Typical results using this calculation show contamination of periportal cell preparation with 25-35\% perivenous cells and vice versa $20-30 \%$ contamination of perivenous cells with periportal cells. It has proven difficult to improve these figures significantly. More extensive digitonin destruction does not seem to be the way to go, since in our experience this only decreases cell yield without increasing purity significantly.

\section{References}

1. Thurman, R. G., Kaufman, F. C., and Jungermann, K. (eds.) (1986) Regulation of Hepatic Metabolism. Inter-and Intra Cellular Compartmentation (Plenum, New York).

2. Katz, N., Teutsch, H. F., Sasse, D., and Jungermann, K. (1977) Heterogeneous distribution of glucose-6-phosphatase in micro dissected periportal and perivenous rat liver tissue. FEBS Lett. 76, 226-230.

3. Guder, W. G. and Schmidt, U. (1976) Liver cell heterogeneity. The distribution of pyruvate kinase and phosphoenolpyruvate carboxykinase in the lobule of fed and starved rats. Hoppe-Seylers Z. Physiol. Chem. 357, 1793-1800.

4. Welsh, F. A. (1972) Changes in distribution of enzymes within the liver lobule during adaptive increases. J. Histochem. Cytochem. 20, 107-111.

5. Mizutani, A. (1968) Cytochemical demonstration of ornithine carbamoyltransferase activity in liver mitochondria of rat and mouse. J. Histochem. Cytochem. 16, 172- 180.

6. Gaasbeek-Janzen, J. W., Lamers. W. H., Morman, A. F., de Graf, A., Los, J. A., and Charles, R. (1984) Immunohistochemical localization of carbamoylphosphate synthetase in adult rat liver. J. Histochem. Cytochem. 32, 557-564.

7. Trus, M., Zawalich, J., Gaynor, D., and Matschinsky, F. M. (1980) Hexokinase and glucokinase distribution in the liver lobule. J. Histochem. Cytochem. 28, 579-581.

8. Smith, M. T. and Wills, E. D. (1981) Effects of dietary lipid and phenobarbitone on the distribution of cytochrome P-450 in the liver studied by quantitative histochemistry. FEBS Lett. 127, 33-36.

9. Gebhardt, R. and Mecke, D. (1983) Heterogeneous distribution of glutamine synthase among rat liver parenchymal cells in situ and in primary culture. Embo J. 2, 567-570.

10. Evans, J. L., Quistorff, B., and Witters, L. A. (1988) Zonation of hepatic lipogenic enzymes identified by dual-digitonin-pulse perfusion. Biochem, J., in press.

11. Wolfe, D. and Jungermann, K. (1985) Long-term effects of physiological oxygen concentrations on glycolysis and gluconeogenesis in hepatocyte culture. Eur. J. Biochem. 151, 299-303. 
12. Probst, I. and Jungermann, K. (1983) The glucagon-insulin antagonism and glucagon-dexamethasone synergism in the induction of PEP-carboxy kinase in cultured rat hepatocytes. Hoppe-Seylers Z. Physiol. Chem. 364, 1739-1746.

13. Häussinger, D. (1983) Hepatocyte heterogeneity in glutamine and ammonia metabolism and the role of an intracellular glutamine cycle during ureagenesis in perfused rat liver. Eur. J. Biochem. 133, 418-422.

14. Quistorff, B., Grunnet, N., and Cornell, N. W. (1985) Digitonin perfusion of rat liver. A new approach in the study of intra-acinar and intra-cellular compartmentation in the liver. Biochem. J. 226, 289-297.

15. Lindros, K. O. and Penttilä, K. E. (1985) Digitonin-collagenase perfusion for efficient separation of periportal or perivenous hepatocytes. Biochem. J. 228, 575-560.

16. Quistorff, B. (1985) Gluconeogenesis in periportal and perivenous hepatocytes of rat liver, isolated by a new high-yield digitonin/collagenase perfusion technique. Biochem. J. 229, 221-226.

17. Quistorff, B., Dich, J., and Grunnet, N. (1986) Periportal and perivenous hepatocytes retain their zonal characteristics in primary culture. Biochem. Biophys. Res. Commun. 139, 1055-1061.

18. Pösö, R. A., Penttila, K. E., Suolinna, E. M., and Lindros, K. E. (1986) Urea synthesis in freshly isolated and in cultured periportal and perivenous hepatocytes. Biochem. J. 239, 263-267.

19. Jungermann, K. and Katz, N. (1982) Functional hepatocellular heterogeneity. Hepatology 2, 385-395.

20. Jungermann, K. (1986) Functional heterogeneity of periportal and perivenous hepatocytes. Enzyme 35, 161-180.

21. Gumucio, J. J. and Chianale, J. (1988) Liver cell heterogeneity and liver function, in The Liver, Biology and Pathology (Arias, I.M., Jakoby, W. B., Popper, H., and Schachter, D., eds.), Raven, New York, pp. 931-948.

22. Quistorff, B. and Grunnet, N. (1987) Dual-digitonin-pulse perfusion. Concurrent sampling or periportal and perivenous cytosol of rat liver for determination of metabolites and enzyme activities. Biochem. J. 243, 87-95.

23. Quistorff, B. (1987) Digitonin perfusion in the study of metablic zonation of the rat liver: Potassium as an intracellular concentration reference. Biochem. Soc. Transact. $15,361-363$. 